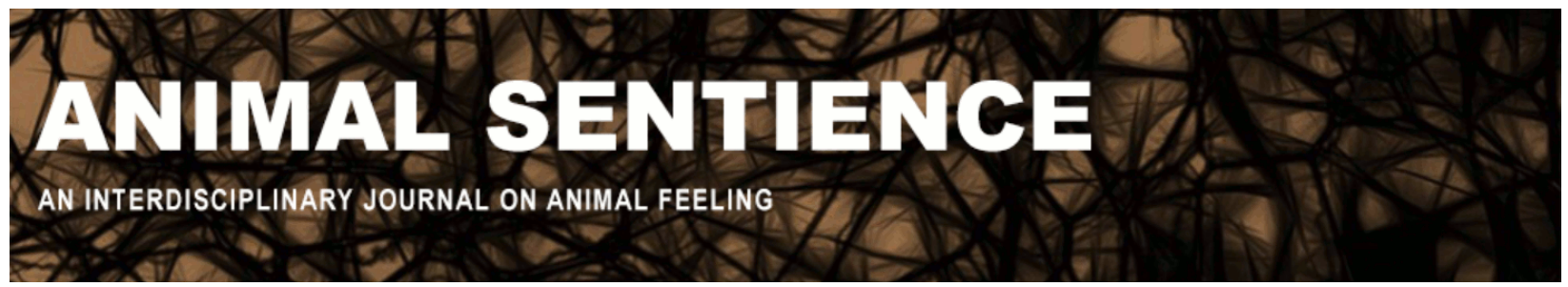

Bergstrom, Bradley J. (2019) Just reductionism: In defense of holistic conservation. Animal Sentience 27(8)

DOI: $10.51291 / 2377-7478.1535$

Date of submission: 2019-12-01

Date of acceptance: 2019-12-11

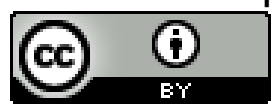

This article has appeared in the journal Animal

Sentience, a peer-reviewed journal on animal

cognition and feeling. It has been made open access,

free for all, by WellBeing International and deposited

in the WBI Studies Repository. For more information,

please contact

wbisr-info@wellbeingintl.org.

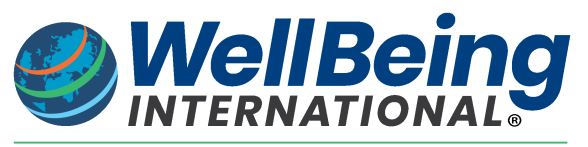

SOLUTIONS FOR PEOPLE, ANIMALS AND ENVIRONMENT 


\title{
Just reductionism: In defense of holistic conservation
}

Commentary on Treves et al. on Just Preservation

\author{
Bradley J. Bergstrom \\ Biology, Valdosta State University
}

\begin{abstract}
Treves et al. (2019) argue that individual organisms should be protected by the courts. This already happens in many countries for rare and endangered species and for symbolically important species (e.g., raptors, songbirds, and bats in the U.S.), and through the international treaty for whales. But protection of these individuals stems from a focus on preserving their populations, whereas hunting of individuals is still a culturally accepted practice. Killing of individuals should be limited to valid reasons (e.g., eating the meat) and covered by fair-chase and humane-killing laws (which is not always the case). But "futurity" will not inherit present-day individuals. What we owe them are healthy populations and species, and functioning, diverse biotic systems. Conservation biology is already rightly focused on this holistic view. Finally, empowerment of women and reform of economic systems will do more to stem the loss of biodiversity than adjudication beyond that already in service of protecting vulnerable species.
\end{abstract}

Brad Bergstrom is Professor of Biology at Valdosta State University. His research interests are in higher vertebrate ecology and conservation. Website

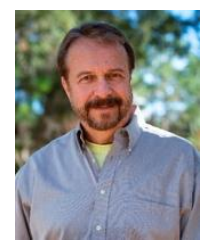

I will start with the disclosure that I am neither a philosopher nor a social scientist - fields which necessarily inform conservation goals - and my day job precludes fully digesting the unexplained, jargonistic arguments referenced by Treves et al. (2019) in their hundred citations. But I commend the authors for recognizing the dire prospects for preserving our biosphere on our present course, and for their optimism in the hope that a radical restructuring of our private and public ethics and institutions can turn things around.

I am an ecologist and conservation biologist, though, and I do not agree that humanity's failure to address the biodiversity crisis is the fault of conservation biology - which after all is the hard science, and one of several academic disciplines, that supports the goal of conservation nor that the field matured with a "muddled ethic." If we are mostly concerned about "futurity" (and I submit "posterity" better fits what we're talking about, because it emphasizes the natural heritage we bequeath our human and non-human "descendants"), then surely the species must be given higher priority than the individual, because its lifespan is many orders of magnitude longer (a bit less so for sequoias and bristlecone pines!).

Here, I agree with Washington's (2019) critique. Save for those few species composed of individuals with great longevity, our great grandchildren will not be negatively affected by loss of individuals nearly as much as by the disappearance of species and by the decline in populations (and numbers of individuals), in genetic diversity within those groups, and in the interactions and relationships among diverse communities of species that comprise functioning ecosystems. These are all levels of biodiversity that conservation biology fully and rightly embraces (Soule 1985). For 
example, extirpation of a strongly interacting species (Payne 1980), or even a reduction in its population below "ecologically effective densities" from one ecosystem, may cause the "extinction" of an important ecological interaction (Janzen 1974).

I see the ethics of human valuation and the treatment of non-human individuals as important but separate from conservation, especially in the case of non-vulnerable species. Even as Descartes was devaluing non-human animals in Europe, in 1641, the Massachusetts Bay Colony charted an opposite course and established humane treatment laws for domestic animals (Francione 1996); unfortunately, 11 years earlier they began bounties on gray wolves, which culminated in their extirpation from New England by 1840 (Benfy 2013). In significant parts of our society today, valuation of species of wild predators has not advanced in these four centuries (Bergstrom et al. 2009).

Later in his life, President Theodore Roosevelt (TR), a noted naturalist and hunter, extended his ethic of humane treatment of domestic animals to wild animals, but he had a strong passion for preservation of all wild species and a holistic view of our natural heritage as the current generation's "duty to the whole, including the unborn generations, [which] bids us to restrain an unprincipled present-day minority from wasting the heritage of these unborn generations" (TR in 1916, as quoted by Brinkley 2009). Futurity indeed. TR established 150 national forests, over 30 national wildlife refuges, and over 20 national parks and monuments.

Although I think they could be much more tightly regulated in many cases, is conservation (or preservation) worse off because regulated hunting and tree harvests are allowed on some of these federal public lands? Just drive through some private timberlands if you don't know the answer to this question. TR is in many ways the grandfather of American conservation, and Aldo Leopold is his heir. Although Leopold disavowed his early career as a predator control agent and came to value the individual, he never became anti-hunting, a position that Treves et al. (2019) seem to be on the verge of articulating. Leopold (1949) noted, "A thing is right when it tends to preserve the integrity, stability, and beauty of the biotic community. It is wrong when it tends otherwise." His land ethic took egocentrism and anthropocentrism out of conservation biology, put the focus on functioning natural ecosystems retaining all their "parts," and is still the closest thing to a guiding philosophy we have. Conservation biology since then has mainly focused on refining what drives integrity and stability in biotic communities; in other words, perfecting the wheel, not reinventing it.

To survive, every heterotrophic organism is necessarily a predator (although non-human herbivores' and human vegans' prey are not sentient) and is also ultimately prey, or some other species' "natural resource." That Homo sapiens uniquely kills more prey and takes more resources of every variety than it needs has been an inexorable reality since the agricultural "takers" outcompeted the hunter-gatherer "leavers" (Quinn 1992), perhaps an inevitable result of the evolution of our "big brains," which has made us poor planetary citizens (Vonnegut 1985) and has left us with exponential growth in technology for technology's sake.

Treves et al. are right to criticize technology and not cling to it as the biosphere's hope, as many environmentalists do. But is their prescription of planetary self-governance and Courts of Nature (is that one per each of the world's 200 countries, or just one for the whole world?) any more realistic? I wish I shared their optimism about such an unprecedented outcome of feedforward control of human excesses. If only Bhutan could take over the world. If humanity did have such capacity of shared will - and it had better develop it in 10 to 15 years before we pass 
the tipping point of anthropogenic climate change, after which much of life is doomed regardless (IPCC 2019) - I would argue a much more salutary strategy for the sake of Gaia is to freeze and then roll back human population growth rather than grant full civil rights to all non-human individuals. In fact, it is more important for preservation of the biosphere that women in all of Earth's societies and cultures be granted not only civil rights but equality. Though challenging, that is a more achievable goal than civil rights for individual non-humans, and it will do much more to halt the great amplifier, if not underlying cause, of all environmental degradation.

Once the human population is reduced, per-capita consumption of the resources of land and sea (including water, air, soil, standing-crop root biomass, and all levels of biodiversity) must be reduced by widespread global agreement and cooperation. Here again, empowered women, especially in rural, agricultural societies, play a key role in environmental sustainability (Aditya 2016). Making this an even more urgent goal is the fact that these societies largely exist in key hotspot areas of global biodiversity (Ricketts et al. 2005).

Adjudication by courts (national or world) is not likely to be the primary and most efficacious means of achieving the preservation of nature, given the recent pullout of the United States from international agreements like the Paris Climate Commitment and its long-time refusal to submit to international courts. Evolution of economic systems away from the pathology of endless economic growth (which will become self-defeating as nature's economy votes last) may be more powerful. Adoption of the Genuine Progress Indicator (GPI), which accounts for environmental degradation and erosion of social justice - to replace the Gross Domestic Product (GDP) - which counts pollution, over-exploitation, and medical costs of environmental degradation as positives - would be a single prescription that could move the world toward sustainability, including slowing the loss of biodiversity (Victor 2010). This would trigger laws and practices that raise the economic costs of greenhouse gas emissions (e.g., carbon taxes) that are destroying the Earth's natural capital. I don't discount the role of the courts, but they must work to enforce laws and constitutions that are not yet up to the task. A test case is in progress in Canada, where 15 youth have filed a lawsuit against their government for violating the national charter and public trust doctrine in failing to prevent climate change (Suzuki 2019).

The 1973 U.S. Endangered Species Act was a great and groundbreaking idea and has prevented the extinction of many species (at times aided by federal courts); it also spawned a global non-governmental effort to evaluate the threats to all species of life (The IUCN Red List). Australia's 1999 Environment Protection and Biodiversity Conservation Act is, in principle, an improvement on the Endangered Species Act in that it recognizes and designates endangered biotic communities. It is a move toward a more holistic view of nature, while still evaluating risks to species survival separately. A shift of focus onto individual organisms - especially those that are not threatened or declining - is a form of reductionism that implicitly denies the emergent properties of ecosystems and the ecosphere. In my view, although it may increase societies' regard for the intrinsic value of every organism, it does not advance the cause of conservation. 


\section{References}

Aditya, S.K. (2016). Role of women in environmental conservation. International Journal of Political Science and Development 4, 140-145.

Benfy, N. (2013). The lost wolves of New England. The New York Review of Books.

Bergstrom, B.J., Vignieri, S., Sheffield, S.R., Sechrest, W., \& Carlson, A.A. (2009). The Northern Rocky Mountain gray wolf is not yet recovered. BioScience 59, 991-999.

Brinkley, D. (2009). The Wilderness Warrior: Theodore Roosevelt and the Crusade for America. New York, NY: Harper Collins.

Francione, G. (1996). Rain without Thunder: The Ideology of the Animal Rights Movement. Philadelphia, PA: Temple University Press.

Intergovernmental Panel on Climate Change [IPCC]. (2019). Special Report: Global Warming of $1.5^{\circ} \mathrm{C}$.

Janzen, D.H. (1974). The deflowering of Central America. Natural History Magazine 83, 48-53.

Leopold, A. (1949). A Sand County Almanac: And Sketches Here and There. London, UK: Oxford University Press.

Paine, R.T. (1980). Food webs: Linkage, interaction strength and community infrastructure. Journal of Animal Ecology 49, 666-685.

Quinn, D. (1992). Ishmael. New York, NY: Bantam Books.

Ricketts, T.H. (2005). Pinpointing and preventing imminent extinctions. Proceedings of the National Academy of Sciences 102, 18497-18501.

Soule, M.R. (1985). What is conservation biology? BioScience 35, 727-734.

Suzuki, D. (2019). 15 Canadian youth launch Canada's first federal youth climate lawsuit to protect their charter and public trust rights. David Suzuki Foundation, Inc.

Treves, A., Santiago-Ávila, F.J., \& Lynn, W.S. (2019). Just preservation. Animal Sentience 27(1).

United Nations Population Fund [UNFPA]. (1994). Issue 7: Women Empowerment.

Victor, P. (2010). Questioning economic growth. Nature 468, 370-371.

Vonnegut, K. (1985). Galapagos: A Novel. New York, NY: Delacourt Press.

Washington, H. (2019). Justice for nature. Animal Sentience 27(2). 